\title{
Miranda
}

Revue pluridisciplinaire du monde anglophone /

Multidisciplinary peer-reviewed journal on the English-

speaking world

23 | 2021

Modernist Exceptions

\section{Modernist Exceptions}

Introduction

\section{Nicolas Pierre Boileau and Charlotte Estrade}

\section{(2) OpenEdition}

\section{Journals}

Electronic version

URL: https://journals.openedition.org/miranda/42213

DOI: 10.4000/miranda.42213

ISSN: 2108-6559

\section{Publisher}

Université Toulouse - Jean Jaurès

Electronic reference

Nicolas Pierre Boileau and Charlotte Estrade, "Modernist Exceptions", Miranda [Online], 23 | 2021,

Online since 11 October 2021, connection on 29 November 2021. URL: http://journals.openedition.org/ miranda/42213 ; DOI: https://doi.org/10.4000/miranda.42213

This text was automatically generated on 29 November 2021.

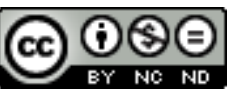

Miranda is licensed under a Creative Commons Attribution-NonCommercial-NoDerivatives 4.0 International License. 


\title{
Modernist Exceptions
}

\author{
Introduction
}

\author{
Nicolas Pierre Boileau and Charlotte Estrade
}

1 Modernism's seminal "Make it New" has long acclaimed exceptionalism as part of the artistic movement's reaction(s) to previous modes of thinking, writing and producing art. Indeed, modernism's wish to renew literature, to experiment with language and to construct itself against previous modes of thinking and writing has enabled writers and artists to rethink the artistic, social and cultural codes or rules of the beginning of the $20^{\text {th }}$ century, either openly, or in a more covert fashion. The gradual expansion of the field of Modernist studies and the growing inclusion of authors and works into the canon raise the issue of whether modernism's exceptionalism remains a discriminating criterion to define a corpus of texts, and it enables critics to specify what this exceptionalism means, in terms of literary composition and linguistic innovation, as well as in terms of circulation (Aji et al.). Despite these general features, redefining the notion of exception also questions the relation between the collective and the individual. This has been formulated and experimented by authors in various ways, whether theoretically and/or creatively.

2 Modernism has produced exceptional literary and artistic figures, who have in turn been viewed as sole examples or unique precursors of their kind, as the titles of many studies suggest: Hugh Kenner's 1972 Pound Era (challenged by Marjorie Perloff's 1982 article entitled "Pound/Stevens: Whose Era"), "the case of Mina Loy" evoked as a particularity in Shari Benstock's Women of the Left Bank: Paris 1900-1940 (381) or David Dowling's Bloomsbury Aesthetics and the novels of Forster and Woolf (1985) have singled out specific authors as modernist exceptions. In the same way, some modernist works have been characterized as exceptional due to the innovative and experimental dimensions of their stylistic or thematic features, sometimes in a paradoxical way. Indeed, when Eliot commented on Joyce's Ulysses in 1923, he expressed the Irish author's uniqueness thus:

In [Ulysses] Joyce has arrived at a very singular and perhaps unique literary distinction: the distinction of having, not in a negative but a very positive sense, no style at all. I mean that every sentence Mr. Joyce writes is peculiarly and absolutely 
his own; that his work is not a pastiche; but that nevertheless, it has none of the marks by which a 'style' may be distinguished. (Eliot in Dowden 45) comparison with other types of writing, which raises the question of the exceptional artist's link with the literary community, as well as the relation between the exceptional character and others in the economy of literary works.

odernism seems to have long been analysed as a moment, or an event, that sounded the borders of language, exploring the subject and subjectivity through and through, to the extent that the created voice was either perceived as irrevocably singular, out of the ordinary or common experience (Cohn; Minow-Pinkney) or reaching a degree of impersonality (Ellmann), which meant that artists sowed the seeds of exceptionalism only to reap their own disappearance or death (to paraphrase Foucault's and Barthes' seminal essays on the structural re-interpretation of the function of the author).

5 Previously unseen modes of composition and previously unread types of texts were produced by representatives of "high modernism" as well as other, lesser-known authors. While some have praised the failure of signification these aesthetic choices resulted into (Alfandary and Nesme 10), others took issue with the unreadability of the texts they caused and its undemocratic politics-for example when Bloomsbury is regarded as the authoritative centre of the movement. ${ }^{1}$ The exceptional nature of the Modernist texts has unfailingly been related to

four great preoccupations: with the complexities of its own form, with the representation of inward states of consciousness, with a sense of the nihilistic disorder behind the ordered surface of life and reality and with the freeing of narrative art from the determination of an onerous plot. (Bradbury and McFarlane 393)

6 Every attempt at defining Modernist aesthetics and strategies seems to come down to trying to capture the essence of works that precisely seek to escape definitions other than in the negative, in their breaking free from past norms and methods. Most conclude on the plurality and multiplicity of the movement (Childs; Wollaeger and Eatough). We have chosen instead to start from the idea that the plurality of practices was the sign of a quest for an exceptional text, always renewed, always conducive to new meanings and unstoppable significations.

Yet in the process, the very notion of exception was questioned and qualified by some exceptional authors. How can one forcefully express one's exceptional status while being an outsider or while defending lesser-known opinions, or in unusual forms of writing? The first two articles which constitute the first part of this collection seek to define exceptionalism in the context of marginal writing practices. Isabelle Brasme shows how Mary Borden's hybrid war writings take issue both with dominant male accounts of the war and with the stereotypical image of the sanctified nurse. The marginal female voice of Mary Borden thus affords us with a displaced and renewed stance on exceptionality. Anne Reynès-Delobel's article then brings related terms into the discussion: with the American literary "Anonymous" project, does exceptionality become synonymous with impersonality, depersonalization or anonymity, or none of these? How can exceptionality coincide with a collective project with transatlantic ramifications? Both articles therefore invite us to re-think subjectivity as not necessarily embodied in one person and as a concept challenged within writing 
practices themselves in the Modernist era. They somehow partially, or temporarily, read exceptionalism as congruent with commonality and shared experience.

In a second stage, Juliana Lopoukhine and Aurore Clavier focus on two female authors whose artistic practices and methods engage both with the exceptional and the unexceptional, the unusual and the mundane, the canonical and the marginal, the central and the peripheral. Focusing respectively on Jean Rhys and Marianne Moore, Lopoukhine and Clavier underline the relatively late appropriation of Rhys and Moore in the field of modernist studies, and the artists' fluid negotiation between different meanings of the exception as singular yet also representative of a group. Eventually, both stress the political implications of such a dialectic. The exceptionality of these works enables us to redefine Modernism away from its central concerns-formal, ethical and political-and to situate it at a vulnerable, yet empowering place of junction, working at the intersection between the humble voices of the commoners and the authoritative assertions of canonical figures.

Eventually, three articles are dedicated to a reappraisal of some more specific characters to consider to what extent they carry, fulfil or jeopardise the experimental nature of Modernist exceptional and outstanding works. Leslie De Bont, in her article on Stella Benson's 1919 novel Living Alone, presents us with a feminine, sometimes comical character, who is exceptional because of her disability. The last two articles analyze characters (Joyce's Stephen Dedalus and Conrad's Kurtz) who have been regarded as exceptional figures of Modernism and can now be reconsidered, not necessarily in order to tone down their exceptional nature or the interpretation of their functions, but to qualify the univocal reception of their exceptionality so as to replace (and replay?) their achievement in the Modernist heritage.

What this collection of articles demonstrates is the fluidity of Modernist practices and the variety of its authors' strategies. Modernist writings remain characterised by their experimental nature and the injunction to force readers to open up to an everchanging world by fragmenting the experience of reading, by changing perspectives and, at times, even by rejecting any form of norms and set ways of thinking. However, more importantly perhaps, this collection gives a voice to humble writers, lesserknown figures, who engage in writing practices, put literature to the test of the modern times, and ultimately refine our understanding of this artistic movement which, unlike others, seems to have allowed writers to be excepted from the centre while not becoming marginal, to be hailed as exceptional while recognised as not without their flaws and ambiguities. In other words, modernism is and remains "new" because it never ceases to give us a glimpse into the challenges of going through an untrodden path.

\section{BIBLIOGRAPHY}

Aji, Hélène, Mansanti, Céline and Tadié, Benoît. Revues modernistes, revues engagées. Rennes: Presses Universitaires de Rennes, 2011. 
Alfandary, Isabelle and Nesme, Axel. Modernism and Unreadability. Presses Universitaires de la Méditerranée, 2011.

Benstock, Shari. Women of the Left Bank: Paris 1900-1940. Austin: University of Texas Press, 1987.

Bradbury, Malcom and McFarlane, James (eds.). Modernism: A Guide to European Literature, 1890-1930. Hardmondsworth, Penguin, 1991.

Childs, Peter. Modernism. New York: Routledge, 2000.

Cohn, Dorrit. Transparent Minds: Narrative Modes for Presenting Modes of Consciousness in Fiction. Princeton, N.J.: Princeton University Press, 1978.

Dowden, Stephen D. Modernism and Mimesis. Palgrave Macmillan, 2020.

Dowling, David. Bloomsbury Aesthetics and the novels of Forster and Woolf. London, Basingstoke: Macmillan, 1985.

Ellmann, Maud. The Poetics of Impersonality: T.S. Eliot and Ezra Pound. 1987. Cambridge, Mass.: Harvard University Press, 2013.

Kenner, Hugh. The Pound Era. London: Faber and Faber, 1972.

Lanone, Catherine. "Art and the 'Second Darkness'." Cahiers victoriens et édouardiens 62 (Oct. 2005): 109-120.

Minow-Pinkney, Makiko. Virginia Woolf and the Problem of the Subject. New Brunswick: Rutgers University Press, 1987.

Oudart, Clément. "Introduction. Modernist Revolutions: American Poetry and the Paradigm of the New." Transatlantica, 1:16 (2016). Accessed 22/09/21. <https://doi.org/10.4000/transatlantica. 8187>.

Perloff, Marjorie. “Pound/Stevens: Whose Era.” New Literary History 13:3 (Spring 1982): 485-514.

Wollaeger, Mark, and Eatough, Matt (eds.). The Oxford Handbook of Global Modernisms. Oxford: Oxford University Press, 2012.

\section{NOTES}

1. "In recent years, Bloomsbury has been both mythologized and questioned. Terry Eagleton, for instance, has contrasted what he sees as the minor art of Bloomsbury, with 'its enclosed and elitist circle of friends,' with the major art produced by exiled modernists who were able to grasp the totality of society, such as James Joyce and T.S. Eliot. Bloomsbury has been equally loathed by Marxists like Charles Harrison and by American right-wing critics like Gertrude Himmelfard." (Lanone 119) 


\section{AUTHORS}

NICOLAS PIERRE BOILEAU

Université Aix-Marseille

Maître de conférences

nicolas.boileau@univ-amu.fr

\section{CHARLOTTE ESTRADE}

Université Paris Nanterre

Maîtresse de conférences

cestrade@parisnanterre.fr 